\title{
Sex differences in the mortality rate for coronavirus disease 2019 compared to other causes
} of death

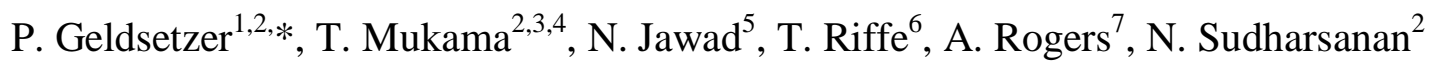

${ }^{1}$ Division of Primary Care and Population Health, Department of Medicine, Stanford University, Stanford, California, USA.

${ }^{2}$ Heidelberg Institute of Global Health, Heidelberg University, Heidelberg, Germany.

${ }^{3}$ Division of Preventive Oncology, National Center for Tumor Diseases (NCT), German Cancer Research Center (DKFZ), Heidelberg, Germany.

${ }^{4}$ Department of Disease Control and Environmental Health, School of Public Health, College of Health Sciences, Makerere University, Kampala, Uganda.

${ }^{5}$ Stanford University School of Medicine, Stanford, California, USA.

${ }^{6}$ Laboratory of Population Health, Max Planck Institute for Demographic Research, Rostock, Germany.

${ }^{7}$ Department of Medicine, Stanford University School of Medicine, Stanford, California, USA.

\section{* Correspondence to:}

Pascal Geldsetzer, Division of Primary Care and Population Health, Department of Medicine, Stanford University, 1265 Welch Road, Stanford, California 94305, USA

E-mail: pgeldsetzer@stanford.edu

Abstract: Men are more likely than women to die due to coronavirus disease 2019 (COVID-19). This paper sets out to examine whether the magnitude of the sex differences in the COVID-19 mortality rate are unusual when compared to other common causes of death. In doing so, we aim to provide evidence as to whether the causal pathways for the sex differences in the mortality rate of COVID-19 likely differ from those for other causes of death. We found that sex differences in the age-standardized COVID-19 mortality rate were substantially larger than for the age-standardized all-cause mortality rate and most other common causes of death. These differences were especially large in the oldest age groups.

One Sentence Summary: The sex difference in the mortality rate of coronavirus disease 2019 is substantially larger than for other common causes of death. 


\section{Main Text:}

\section{Introduction:}

Males have a higher risk of death from coronavirus disease 2019 (COVID-19) than females ${ }^{1-6}$. This difference has been observed for both the case fatality rate (CFR; i.e., deaths among those diagnosed with a SARS-CoV-2 infection) and infection fatality rate (IFR; i.e., deaths among all those who were infected with SARS-CoV-2) ${ }^{1}$. This higher risk of death from COVID19 in males has been highlighted both in the academic literature and the media ${ }^{7-9}$.

Understanding why these disparities by sex exist has become an active area of research. However, given that the risk of death from COVID-19 is strongly related to one's expected remaining life expectancy ${ }^{6}$, it is unclear whether the observed sex differences in the COVID-19 fatality rate are simply a reflection of men's shorter life expectancy ${ }^{10}$, which is at least in part due to their poorer health status at any given age. This study aimed to determine if sex differences in COVID-19 mortality are larger when compared to the all-cause mortality rate, mortality rates for other common causes of death, and - given SARS-CoV-2's common respiratory manifestations - other respiratory causes of death, including respiratory infections. This information is crucial, as it begins to elucidate whether the higher COVID-19 mortality risk among males reflects the survival advantage among females compared to males, and is, thus, likely a result of the biological, behavioral, and social pathways that cause this survival advantage as opposed to causal pathways that are specific to COVID-19. Understanding these causal pathways could help in the development of therapeutics and preventive measures for COVID-19 and future coronavirus disease outbreaks.

\section{Results:}

We extracted the latest available country-level data on COVID-19 deaths from the COVerAGEDB for countries for which age- and sex-disaggregated data were available (as of 09 February 2021) ${ }^{11}$. We then obtained age- and sex-disaggregated data on all-cause mortality and population size for each of these countries from the Human Mortality Database (HMD) ${ }^{12}$ and, for countries not included in the HMD, from the United Nation's World Population Prospects (WPP) ${ }^{10}$. The latest available mortality data for specific causes of death were drawn from the World Health Organization's (WHO) mortality database ${ }^{13}$. We then calculated the ratios for the sex difference in the COVID-19 mortality (i.e., the ratio of the number of COVID-19 deaths in men divided by the male mid-year population to the number of COVID-19 deaths in women divided by the female mid-year population) and compared these ratios to those for i) all-cause mortality, ii) each of the six most common causes of death groups globally for adults (excluding injuries) ${ }^{14}$, and iii) each major respiratory cause of death.

Age- and sex-disaggregated data on COVID-19 deaths were available for 59 countries (Table 1). 


\begin{tabular}{|c|c|c|c|c|c|c|c|c|}
\hline \multirow[b]{2}{*}{ Country } & \multirow[b]{2}{*}{ Period/year $\dagger$} & \multicolumn{2}{|c|}{ Population (000s) } & \multicolumn{2}{|c|}{$\begin{array}{c}\text { All-cause mortality } \\
\text { Deaths (000s) }\end{array}$} & \multirow[b]{2}{*}{ Date* } & \multicolumn{2}{|c|}{$\begin{array}{c}\text { COVID-19 mortality } \\
\text { Deaths }\end{array}$} \\
\hline & & Female & Male & Female & Male & & Female & Male \\
\hline Afghanistan & $2015-2020$ & 18,952 & 19,976 & 549 & 646 & 28.11 .2020 & 381 & 1,130 \\
\hline Argentina & $2015-2020$ & 23,147 & 22,049 & 802 & 878 & 15.01 .2021 & 19,648 & 26,539 \\
\hline Australia & 2018 & 12,495 & 12,298 & 76 & 82 & 07.02 .2021 & 468 & 441 \\
\hline Belgium & 2018 & 5,794 & 5,630 & 57 & 54 & 07.02 .2021 & 10,880 & 10,479 \\
\hline Brazil & $2015-2020$ & 108,124 & 104,436 & 2,901 & 3,790 & 01.02 .2021 & 84,023 & 111,936 \\
\hline Canada & 2018 & 18,513 & 18,249 & 139 & 144 & 22.09 .2020 & 4,516 & 4,672 \\
\hline Chad & $2015-2020$ & 8,226 & 8,200 & 445 & 490 & 21.10 .2020 & 27 & 65 \\
\hline Chile & 2017 & 8,923 & 8,573 & 51 & 56 & 13.01 .2021 & 7,449 & 9,986 \\
\hline Colombia & $2015-2020$ & 25,898 & 24,985 & 617 & 742 & 07.02 .2021 & 22,852 & 40,064 \\
\hline Croatia & 2018 & 2,124 & 1,982 & 27 & 26 & 20.12 .2020 & 345 & 332 \\
\hline Cuba & $2015-2020$ & 5,703 & 5,623 & 239 & 266 & 24.05 .2020 & 33 & 49 \\
\hline Cyprus & $2015-2020$ & 604 & 604 & 20 & 22 & 29.11 .2020 & 40 & 103 \\
\hline Czechia & 2018 & 5,390 & 5,220 & 56 & 57 & 07.02 .2021 & 7,167 & 9,327 \\
\hline Denmark & 2019 & 2,917 & 2,889 & 27 & 27 & 02.02 .2021 & 995 & 1,165 \\
\hline Ecuador & $2015-2020$ & 8,819 & 8,824 & 188 & 243 & 31.07 .2020 & 3,590 & 7,025 \\
\hline Estonia & 2019 & 699 & 626 & 8 & 7 & 13.12 .2020 & 131 & 97 \\
\hline Eswatini & $2015-2020$ & 590 & 570 & 24 & 29 & 30.12 .2020 & 78 & 106 \\
\hline Finland & 2019 & 2,795 & 2,723 & 27 & 27 & 20.12 .2020 & 270 & 402 \\
\hline France & 2018 & 33,419 & 31,324 & 300 & 297 & 28.01 .2021 & 22,052 & 30,657 \\
\hline Germany & 2017 & 41,824 & 40,697 & 475 & 458 & 07.02 .2021 & 29,827 & 31,839 \\
\hline Greece & 2017 & 5,549 & 5,222 & 61 & 63 & 16.01 .2021 & 2,241 & 3,199 \\
\hline Hungary & 2017 & 5,122 & 4,675 & 68 & 64 & 29.11 .2020 & 296 & 293 \\
\hline Iceland & 2018 & 171 & 178 & 1 & 1 & 29.11 .2020 & 45 & 60 \\
\hline India & $2015-2020$ & 662,903 & 717,101 & 22,515 & 26,158 & 02.10 .2020 & 30,987 & 69,888 \\
\hline Iraq & $2015-2020$ & 19,865 & 20,358 & 417 & 492 & 24.05 .2020 & 50 & 110 \\
\hline Ireland & 2017 & 2,413 & 2,365 & 15 & 15 & 20.12 .2020 & 971 & 1,029 \\
\hline Israel & 2016 & 4,268 & 4,195 & 22 & 22 & 09.12 .2020 & 1,260 & 1,672 \\
\hline Italy & 2017 & 31,121 & 29,404 & 340 & 311 & 05.01 .2021 & 32,481 & 42,567 \\
\hline Japan & 2019 & 63,705 & 60,392 & 674 & 707 & 18.08 .2020 & 294 & 531 \\
\hline
\end{tabular}




\begin{tabular}{|c|c|c|c|c|c|c|c|c|}
\hline Jordan & $2015-2020$ & 5,037 & 5,166 & 84 & 104 & 07.02 .2021 & 1,557 & 2,822 \\
\hline Kenya & $2015-2020$ & 27,053 & 26,719 & 641 & 761 & 11.10 .2020 & 72 & 208 \\
\hline Latvia & 2017 & 1,054 & 896 & 15 & 14 & 29.11 .2020 & 49 & 40 \\
\hline Lithuania & 2019 & 1,499 & 1,296 & 20 & 18 & 29.11 .2020 & 120 & 171 \\
\hline Luxembourg & 2019 & 305 & 309 & 2 & 2 & 20.12 .2020 & 162 & 178 \\
\hline Malawi & $2015-2020$ & 9,696 & 9,434 & 274 & 333 & 27.12.2020 & 45 & 143 \\
\hline Malta & $2015-2020$ & 220 & 221 & 9 & 9 & 20.12 .2020 & 84 & 243 \\
\hline Mexico & $2015-2020$ & 65,861 & 63,071 & 1,688 & 2,058 & 13.01 .2021 & 50,228 & 86,689 \\
\hline Nepal & $2015-2020$ & 15,788 & 13,348 & 437 & 460 & 26.09 .2020 & 101 & 259 \\
\hline Netherlands & 2018 & 8,654 & 8,527 & 79 & 75 & 14.02 .2021 & 6,595 & 7,808 \\
\hline Nigeria & $2015-2020$ & 101,670 & 104,470 & 5,546 & 6,038 & 17.01 .2021 & 306 & 840 \\
\hline Pakistan & $2015-2020$ & 107,220 & 113,672 & 3,364 & 3,974 & 02.06 .2020 & 435 & 1,253 \\
\hline Panama & $2015-2020$ & 2,155 & 2,160 & 44 & 61 & 04.07 .2020 & 219 & 501 \\
\hline Paraguay & $2015-2020$ & 3,508 & 3,624 & 85 & 104 & 16.01 .2021 & 912 & 1,408 \\
\hline Peru & $2015-2020$ & 16,593 & 16,379 & 374 & 491 & 04.02 .2021 & 13,506 & 28,432 \\
\hline Philippines & $2015-2020$ & 54,552 & 55,029 & 1,249 & 1,836 & 04.02 .2021 & 4,404 & 6,713 \\
\hline Poland & 2018 & 19,840 & 18,593 & 201 & 214 & 20.12 .2020 & 1,385 & 2,057 \\
\hline Portugal & 2018 & 5,425 & 4,869 & 56 & 57 & 02.02 .2021 & 6,367 & 6,890 \\
\hline Romania & $2015-2020$ & 9,884 & 9,354 & 621 & 654 & 29.11 .2020 & 362 & 490 \\
\hline Slovakia & 2017 & 2,784 & 2,652 & 26 & 27 & 20.12 .2020 & 964 & 1,047 \\
\hline Slovenia & 2017 & 1,041 & 1,025 & 10 & 10 & 31.01 .2021 & 1,964 & 1,795 \\
\hline South Korea & 2018 & 25,680 & 25,595 & 138 & 161 & 28.06 .2020 & 134 & 148 \\
\hline Spain & 2018 & 23,776 & 22,881 & 210 & 215 & 04.02 .2021 & 27,559 & 33,065 \\
\hline Switzerland & 2018 & 4,278 & 4,206 & 35 & 32 & 08.02 .2021 & 4,121 & 4,747 \\
\hline Togo & 2015-2020 & 4,159 & 4,119 & 164 & 170 & 02.02 .2021 & 18 & 59 \\
\hline Turkey & $2015-2020$ & 42,703 & 41,636 & 997 & 1,201 & 26.10 .2020 & 3,541 & 6,258 \\
\hline Ukraine & 2013 & 24,407 & 20,961 & 338 & 325 & 06.02 .2021 & 7,568 & 9,827 \\
\hline United Kingdom & 2018 & 33,554 & 32,687 & 312 & 304 & 01.01 .2021 & 40,282 & 48,960 \\
\hline Uruguay & $2015-2020$ & 1,795 & 1,678 & 81 & 82 & 18.01 .2021 & 74 & 236 \\
\hline USA & 2018 & 165,365 & 160,460 & 1,381 & 1,458 & 26.12 .2020 & 192,335 & 228,829 \\
\hline
\end{tabular}

Table 1. Population, all-cause deaths, and COVID-19 cases and deaths by sex and country 
${ }^{\dagger}$ Year for which population and deaths data are available in the HMD. Population and mortality projections for the 2015-2020 period from the UN's World Population Prospects (WPP) were used for countries not in the HMD.

*Date when latest sex-disaggregated data were available for each country.

Caption: We extracted latest available population and deaths count data for each country. Population and deaths count data were available for 32 countries from the Human Mortality Database (HMD): Australia, Belgium, Canada, Chile, Croatia, Czechia, Denmark, Estonia, Finland, France, Germany, Greece, Hungary, Iceland, Ireland, Israel, Italy, Japan, Latvia, Lithuania, Luxembourg, Netherlands, Poland, Portugal, Slovakia, Slovenia, South Korea, Spain, Switzerland, Ukraine, United Kingdom and USA. For countries not in the HMD, we obtained the standard projections of population numbers and deaths for the 2015-2020 period from the United Nation's World Population Prospects (WPP) (https://population.un.org/wpp/Download/Standard/Population/). 
medRxiv preprint doi: https://doi.org/10.1101/2021.02.23.21252314; this version posted February 26, 2021. The copyright holder for this preprint (which was not certified by peer review) is the author/funder, who has granted medRxiv a license to display the preprint in perpetuity.

All rights reserved. No reuse allowed without permission.

From this data, we calculated the age-standardized male-to-female rate ratios of mortality from COVID19 and all-causes. The age standardization, conducted separately for each country, was carried out to ensure that differences in the male-to-female mortality rate ratio between COVID-19 and all causes were not confounded by sex differences in the age distribution. Point estimates greater than one in Figure 1 indicate that men had a higher rate of death than women. We found that in most countries, the male disadvantage for COVID-19 mortality was substantially larger than their all-cause mortality disadvantage (Figure 1 and Figure S1). 
medRxiv preprint doi: https://doi.org/10.1101/2021.02.23.21252314; this version posted February 26, 2021. The copyright holder for this preprint (which was not certified by peer review) is the author/funder, who has granted medRxiv a license to display the preprint in perpetuity.

All rights reserved. No reuse allowed without permission.

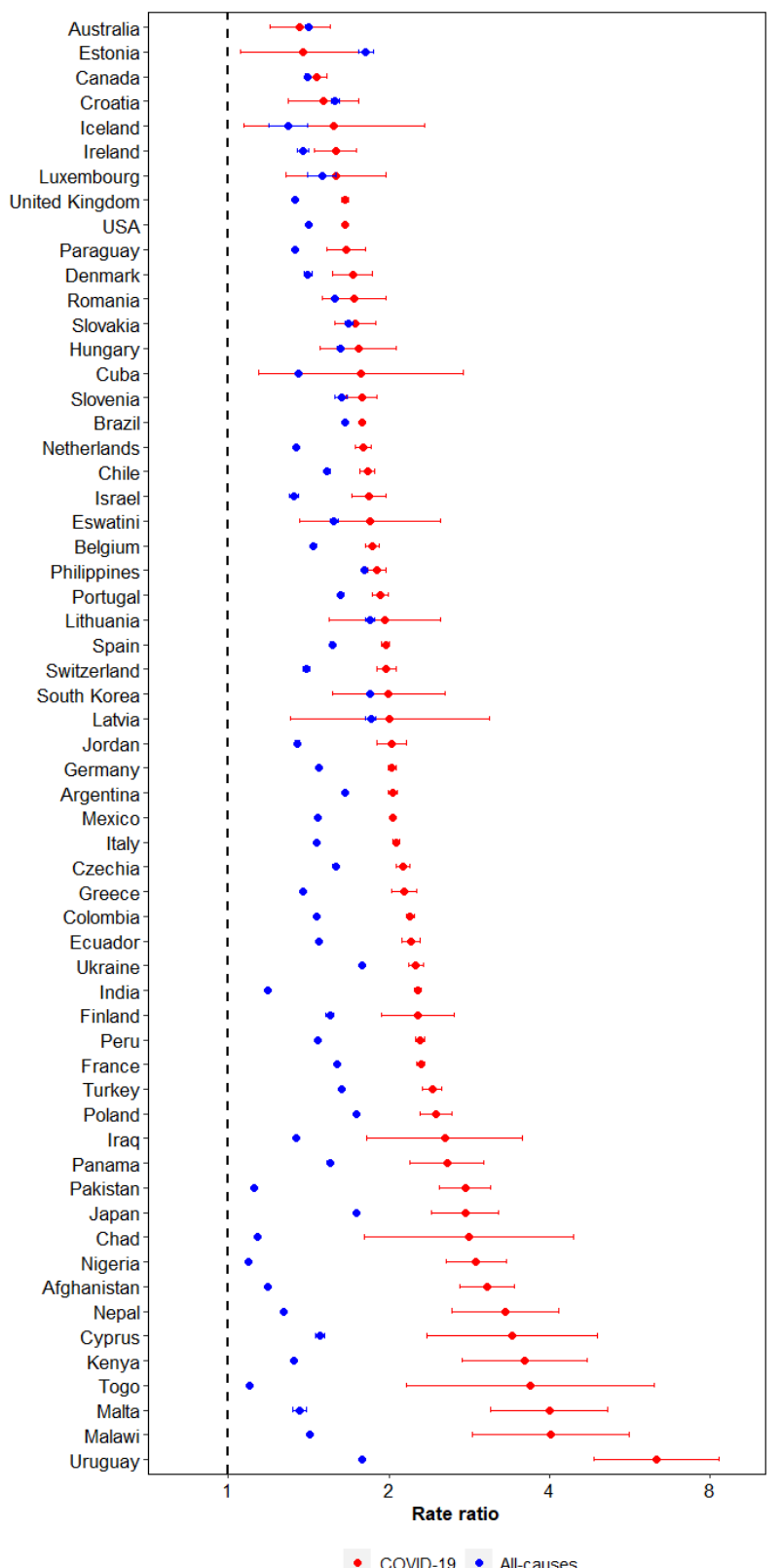

Figure 1. Male-to-female rate ratios of mortality from COVID-19 and all causes.

Caption: Rate ratios for the sex differences in COVID-19 and all-cause mortality were calculated for each country by dividing the age-standardized mortality rate in males by the age-standardized mortality rate in females.

Next, we investigated whether the degree of the male disadvantage in the COVID-19 compared to the all-cause mortality varied by age group. To do so, we divided - separately by ten-year age group - the age-standardized male-to-female rate ratio for the COVID-19 mortality by the age-standardized male-tofemale rate ratio for all-cause mortality. Point estimates greater than one in Figure 2, thus, indicate that the sex differences in the mortality rate for COVID-19 were greater than expected based on the sex differences in the all-cause mortality rate. We found that among the older age groups, especially the group aged 80 years and older, the higher rate of death for men than woman exceeded (in relative terms) that for all-cause mortality for most countries. Among younger age groups, especially those aged less than 50 years, the direction and magnitude of these differences varied greatly by country. These patterns are similar when adjusting these estimates for remaining life expectancy (Figure S2). 
medRxiv preprint doi: https://doi.org/10.1101/2021.02.23.21252314; this version posted February 26, 2021. The copyright holder for this preprint (which was not certified by peer review) is the author/funder, who has granted medRxiv a license to display the preprint in perpetuity.

All rights reserved. No reuse allowed without permission.
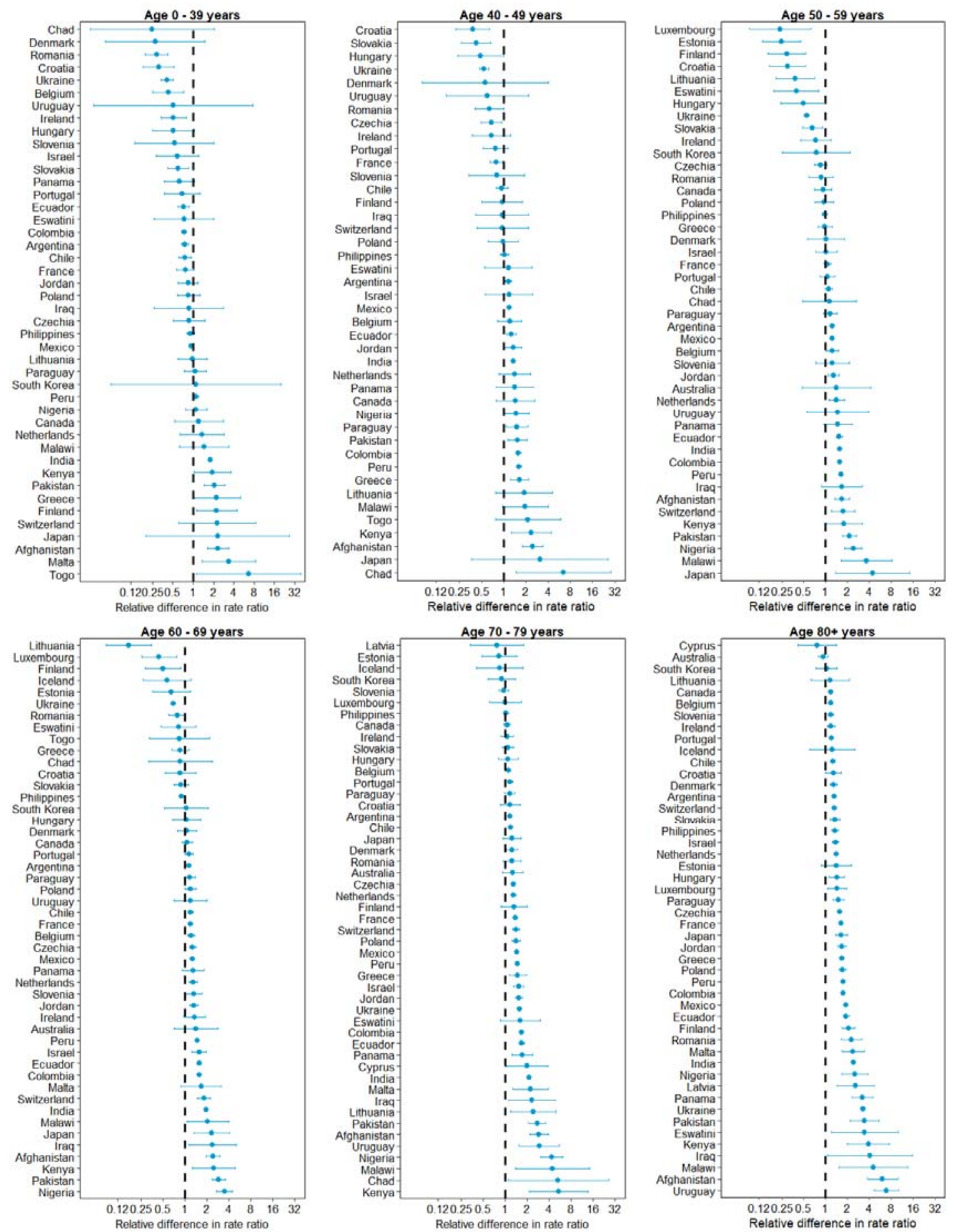

Figure 2. Relative difference in the male-to-female rate ratios of COVID-19-specific and all-cause mortality, by age group.

Caption: The relative difference in the rate ratio was calculated by dividing (separately among each age group shown) the male-to-female rate ratio for the COVID-19-specific mortality rate by the male-tofemale rate ratio for the all-cause mortality rate. 
medRxiv preprint doi: https://doi.org/10.1101/2021.02.23.21252314; this version posted February 26, 2021. The copyright holder for this preprint

(which was not certified by peer review) is the author/funder, who has granted medRxiv a license to display the preprint in perpetuity.

All rights reserved. No reuse allowed without permission.

Using the same metric as for Figure 2, we then compared the relative magnitude of sex differences in the mortality for COVID-19 to that for other major causes of mortality (circulatory diseases, cancer, chronic respiratory diseases, respiratory infections and tuberculosis, diabetes, and neurologic disorders). We found that in most countries the relative sex differences for COVID-19 were larger than for each of the other common causes of death (Figure 3 and Figure S3). However, this was not true for chronic respiratory conditions for which countries were spread approximately equally across the vertical dashed line drawn at one (i.e., the number indicating that the relative sex difference for the COVID-19 mortality was the same as for chronic respiratory diseases). Implementing the same analysis as in Figure 3 for each common respiratory cause of death (the ICD-10 codes used for categorization are shown in Table $\mathrm{S} 2$ ) revealed that the similar male disadvantage in mortality for chronic respiratory diseases as for COVID-19 is largely driven by a high male disadvantage in mortality from bronchitis and emphysema (Figure S4) and, thus, likely the higher prevalence of smoking (especially in the past) among men than women ${ }^{15,16}$. 
medRxiv preprint doi: https://doi.org/10.1101/2021.02.23.21252314; this version posted February 26, 2021. The copyright holder for this preprint (which was not certified by peer review) is the author/funder, who has granted medRxiv a license to display the preprint in perpetuity.

All rights reserved. No reuse allowed without permission.
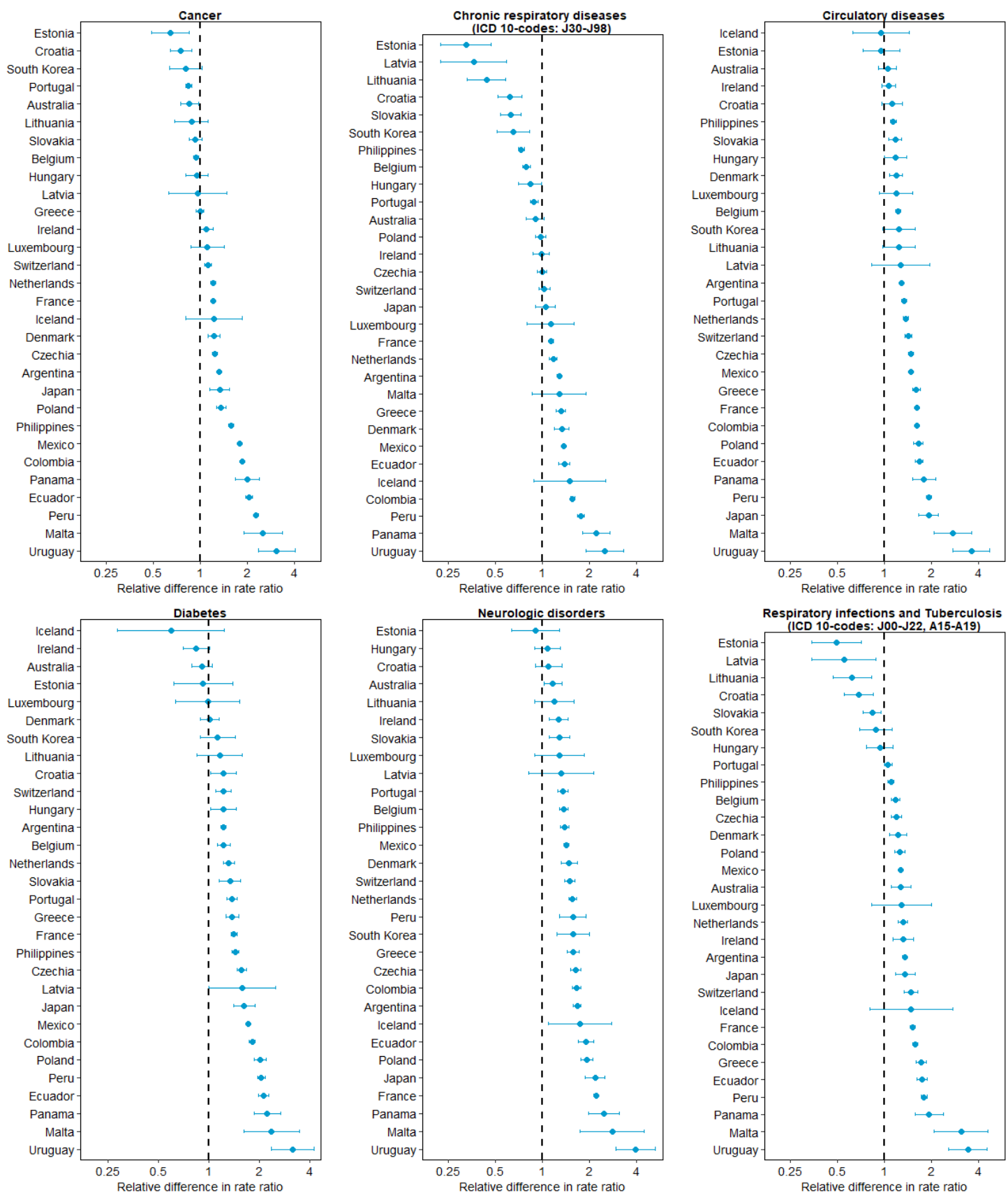

Figure 3. Relative difference in the male-to-female rate ratios of COVID-19-specific mortality and six major causes of mortality 
medRxiv preprint doi: https://doi.org/10.1101/2021.02.23.21252314; this version posted February 26, 2021. The copyright holder for this preprint

(which was not certified by peer review) is the author/funder, who has granted medRxiv a license to display the preprint in perpetuity.

All rights reserved. No reuse allowed without permission.

\section{Discussion:}

The degree to which men are more likely to die from COVID-19 than women is substantially larger than would be expected merely based on the fact that men are generally more likely to die at any given age than women. Thus, the probability of succumbing to a SARS-CoV-2 infection does not appear to be fully explained by the remaining life expectancy of the person who was infected. This observation suggests that the causal pathways that link male sex to a shorter life expectancy may not fully explain the unusually high male disadvantage in COVID-19 mortality. Our findings, therefore, lend support to hypotheses that posit that the causal pathways that link male sex to a higher mortality from a SARSCoV-2 infection are specific to SARS-CoV-2 rather than shared with the pathways responsible for the shorter life expectancy among men than women or the causal pathways for sex differences for other common causes of death.

This study has several limitations. First and foremost, this study can only provide suggestive (as opposed to conclusive) evidence as to whether or not the causal pathways underlying the male disadvantage for COVID-19 mortality are shared with those underlying the all-cause mortality disadvantage for men. Second, our mortality rate calculations for COVID-19 use the total population (by sex) as the denominator. Thus, the assumption underlying the validity of our calculation is that there are no substantial differences in the probability of being infected with SARS-CoV-2 between males and females. To date, evidence from seroprevalence studies suggests that this assumption is reasonable ${ }^{17,18}$. An alternative approach is to use the number of identified cases of SARS-CoV-2 infections as the denominator (i.e., calculating the case fatality rate). This approach, however, assumes that the degree of underdetection of SARS-CoV-2 infections is the same among men as among women. This assumption would, for example, be violated if males are more likely to develop symptoms from a SARS-CoV-2 infection than females and are, therefore, more likely to seek out a COVID-19 test, or if men have better access to testing than women. Although both choices for the denominator (total population or number of cases) rely on untestable assumptions, our analyses in which we use the number of cases instead of the total population as denominator found that the choice of denominator does not substantially change our conclusions.

Studies have hypothesized that the sex differences in COVID-19 mortality exist due to behavioral and social risk factors (e.g., higher incidence of smoking and drinking among men than women) that place men at a greater risk of mortality from health complications associated with COVID-19 ${ }^{19-24}$. Other studies have cited a higher rate of comorbidities, such as diabetes and heart disease, as the reason for the higher COVID-19 fatality rate among men ${ }^{4,25-28}$. Finally, some studies suggest biological factors that may explain these disparities. One potential factor is a higher expression among men than women of the angiotensin-converting enzyme 2 receptor, which is used by SARS-CoV-2 to enter the host cell ${ }^{3,29,30}$. Other possible biological factors relate to immunological differences between males and females ${ }^{31-3 \dot{3}}$. Ultimately a combination of biological, behavioral, and social pathways may be responsible for the high male disadvantage in COVID-19 mortality. Elucidating these causal chains is an important research area given that it may assist in the development of therapeutics and preventive measures for COVID-19 and future outbreaks of coronavirus diseases. 


\section{References and Notes:}

1. Blackburn, J., Yiannoutsos, C. T., Carroll, A. E., Halverson, P. K. \& Menachemi, N. Infection Fatality Ratios for COVID-19 Among Noninstitutionalized Persons 12 and Older: Results of a Random-Sample Prevalence Study. Ann. Intern. Med. (2020) doi:10.7326/M20-5352.

2. Boerner, L. COVID-19 is probably more deadly to men than women, but scientists still aren't sure why. https://cen.acs.org/biological-chemistry/infectious-disease/COVID-19-probably-deadlymen/98/i29 (2020).

3. Gebhard, C., Regitz-Zagrosek, V., Neuhauser, H. K., Morgan, R. \& Klein, S. L. Impact of sex and gender on COVID-19 outcomes in Europe. Biol. Sex Differ. 11, (2020).

4. Jin, J.-M. et al. Gender Differences in Patients With COVID-19: Focus on Severity and Mortality. Front. Public Health 8, (2020).

5. Pradhan, A. \& Olssen, P.-E. Sex differences in severity and mortality from COVID-19: are males more vulnerable? Biol Sex Differ 11, 53 (2020).

6. Williamson, E. J. et al. Factors associated with COVID-19-related death using OpenSAFELY. Nature 584, 430-436 (2020).

7. Alkhouli, M., Nanjundappa, A., Annie, F., Bates, M. C. \& Bhatt, D. L. Sex Differences in Case Fatality Rate of COVID-19: Insights From a Multinational Registry. Mayo Clin. Proc. 95, 16131620 (2020).

8. Bendix, A. \& Secon, H. More men die from coronavirus than women - here's why that might be Business Insider. https://www.businessinsider.com/why-more-men-die-from-coronavirus-thanwomen-2020-3 (2020). 
medRxiv preprint doi: https://doi.org/10.1101/2021.02.23.21252314; this version posted February 26, 2021. The copyright holder for this preprint (which was not certified by peer review) is the author/funder, who has granted medRxiv a license to display the preprint in perpetuity.

All rights reserved. No reuse allowed without permission.

9. Lord, D. Coronavirus fact check: Are more men than women dying from COVID-19?

https://www.kiro7.com/news/trending/coronavirus-fact-check-are-more-men-than-women-dyingcovid-19/JMMCO3I4NBD3XPNHQFEACXVILQ/ (2020).

10. World Population Prospects - Population Division - United Nations. https://population.un.org/wpp/.

11. Riffe, T. et al. COVerAGE-DB: A database of age-structured COVID-19 cases and deaths. medRxiv 2020.09.18.20197228 (2020) doi:10.1101/2020.09.18.20197228.

12. University of California, Berkeley \& Max Planck Institute for Demographic Research. Human Mortality Database. www.mortality.org.

13. World Health Organization. WHO Mortality Database. https://www.who.int/data/data-collectiontools/who-mortality-database (2019).

14. GBD 2019 Diseases and Injuries Collaborators. Global burden of 369 diseases and injuries in 204 countries and territories, 1990-2019: a systematic analysis for the Global Burden of Disease Study 2019. Lancet Lond. Engl. 396, 1204-1222 (2020).

15. Ritchie, H. Who smokes more, men or women? Our World in Data https://ourworldindata.org/whosmokes-more-men-or-women.

16. National Center for Health Statistics. ICD - ICD-10 - International Classification of Diseases, Tenth Revision. https://www.cdc.gov/nchs/icd/icd10.htm (2020).

17. Anand, S. et al. Prevalence of SARS-CoV-2 antibodies in a large nationwide sample of patients on dialysis in the USA: a cross-sectional study. The Lancet 396, 1335-1344 (2020).

18. Ng, O. T. et al. SARS-CoV-2 seroprevalence and transmission risk factors among high-risk close contacts: a retrospective cohort study. Lancet Infect. Dis. 0, (2020).

19. Bwire, G. M. Coronavirus: Why Men are More Vulnerable to Covid-19 Than Women? Sn Compr. Clin. Med. 1-3 (2020) doi:10.1007/s42399-020-00341-w. 
medRxiv preprint doi: https://doi.org/10.1101/2021.02.23.21252314; this version posted February 26, 2021. The copyright holder for this preprint (which was not certified by peer review) is the author/funder, who has granted medRxiv a license to display the preprint in perpetuity.

All rights reserved. No reuse allowed without permission.

20. Drope, J. What We Know About Tobacco Use and COVID-19. https://www.cancer.org/health-careprofessionals/center-for-tobacco-control/what-we-know-about-tobacco-use-and-covid-19.html (2020).

21. Griffith, D. M. Men and COVID-19: A Biopsychosocial Approach to Understanding Sex Differences in Mortality and Recommendations for Practice and Policy Interventions. Prev. Chronic. Dis. 17, (2020).

22. Liu, M. et al. Drinking no-links to the severity of COVID-19: a systematic review and metaanalysis. J. Infect. 81, e126-e127 (2020).

23. World Health Organization. Smoking and COVID-19. https://www.who.int/newsroom/commentaries/detail/smoking-and-covid-19 (2020).

24. Meng, Y. et al. Sex-specific clinical characteristics and prognosis of coronavirus disease-19 infection in Wuhan, China: A retrospective study of 168 severe patients. PLOS Pathog. 16, e1008520 (2020).

25. Capuano, A., Rossi, F. \& Paolisso, G. Covid-19 Kills More Men Than Women: An Overview of Possible Reasons. Front. Cardiovasc. Med. 7, (2020).

26. Guarino, B. Why the coronavirus is killing more men than women. Washington Post.

27. Holman, N. et al. Risk factors for COVID-19-related mortality in people with type 1 and type 2 diabetes in England: a population-based cohort study. Lancet Diabetes Endocrinol. 8, 823-833 (2020).

28. The Lancet. The gendered dimensions of COVID-19. Lancet Lond. Engl. 395, 1168 (2020).

29. Behl, T. et al. The dual impact of ACE2 in COVID-19 and ironical actions in geriatrics and pediatrics with possible therapeutic solutions. Life Sci. 257, 118075 (2020).

30. Ni, W. et al. Role of angiotensin-converting enzyme 2 (ACE2) in COVID-19. Crit. Care 24, (2020). 
medRxiv preprint doi: https://doi.org/10.1101/2021.02.23.21252314; this version posted February 26, 2021. The copyright holder for this preprint (which was not certified by peer review) is the author/funder, who has granted medRxiv a license to display the preprint in perpetuity.

All rights reserved. No reuse allowed without permission.

31. Cunningham, A. COVID-19 kills more men than women. The immune system may be why. Science News https://www.sciencenews.org/article/coronavirus-covid-19-kills-more-men-than-women-whyimmune-system (2020).

32. Klein, S. L. \& Flanagan, K. L. Sex differences in immune responses. Nat. Rev. Immunol. 16, 626$638(2016)$.

33. Geggel, L. Why are more men dying from COVID-19?| Live Science.

https://www.livescience.com/why-covid-19-more-severe-men.html.

34. United Nations, Department of Economic and Social Affairs, Population Division. World Population Prospects 2019: Press Release. (2019).

\section{Acknowledgments}

Funding: PG was supported by the National Center for Advancing Translational Sciences of the National Institutes of Health under Award Number KL2TR003143; Author contributions: Pascal Geldsetzer: conceptualization, methodology, writing - original draft preparation; Trasias Mukama: methodology, data analysis, writing - reviewing and editing; Nadine Jawad: methodology, writing original draft preparation; Tim Riffe: conceptualization, methodology, writing - reviewing and editing; Angela Rogers: methodology, writing - reviewing and editing; Nikkil Sudharsanan: conceptualization, methodology, writing - reviewing and editing; Competing interests: The authors declare no competing interests; Data and materials availability: All the data used in the study are publicly available. COVID-19 mortality data are available from the COVerAGE-DB (https://osf.io/mpwjq/). Data on population size by age and sex are available from the HMD (www.mortality.org) and the United Nation's WPP (https://www.who.int/healthinfo/mortality data/en/). 
medRxiv preprint doi: https://doi.org/10.1101/2021.02.23.21252314; this version posted February 26, 2021. The copyright holder for this preprint (which was not certified by peer review) is the author/funder, who has granted medRxiv a license to display the preprint in perpetuity.

All rights reserved. No reuse allowed without permission. 